\title{
Isolation and Sequences Analysis of Tight Junction Protein Claudin Encoding Genes in Intestinal Barrier of Common Carp (Cyprinus carpio)
}

\author{
Hamdan Syakuri $^{1}$ and Dieter Steinhagen ${ }^{2}$ \\ ${ }^{l}$ Department of Fisheries and Marine Science, Faculty of Science and Technology, Jenderal Soedirman University, \\ Purwokerto, Indonesia \\ ${ }^{2}$ Fish Diseases Research Unit, Center of Infectious Diseases, University of Veterinary Medicine Hanover, Bünteweg 17, \\ D-30559 Hanover, Germany \\ Correspondence to: hsyakuri@gmail.com
}

\begin{abstract}
Hamdan Syakuri and Dieter Steinhagen. 2014. Isolation and Sequences Analysis of Tight Junction Protein Claudin Encoding Genes in Intestinal Barrier of Common Carp (Cyprinus carpio). Aquacultura Indonesiana, 15 (2) : 74-85. Claudins multigene family encode proteins which forms main structures of tight junction among epithelial cells. In intestinal epithelium claudin proteins are proposed to have roles in ion balances regulation and forming barrier against pathogenic invasion. This work was done in order to identify claudin encoding genes in common carp (Cyprinus carpio), one of the most important cultured fish in freshwater aquaculture. Sample of RNA was isolated from the fish and transcribed into cDNA. Carp claudin genes were amplified, cloned, and sequenced. Carp claudin 1 and 2 were amplified with primers designed based on relevant known claudin genes in fish. On the basis of carp ESTs, other six carp claudin genes were amplified by using appropriate primers. Phylogenetic and sequence analysis confirmed that the eight identified genes are claudin genes and could be designated as carp claudin $1,2,3^{\mathrm{b}}, 3^{\mathrm{c}}, 7,11,23$, and 30 , respectively. This finding could be used to develop further study of carp claudin especially roles of claudin during pathogen infection and strategy to modulate its expression in order to protect diseases in carp aquaculture.
\end{abstract}

Keywords: Claudin; Cyprinus carpio; Intestinal barrier

\section{Introduction}

Common carp (Cyprinus carpio) is considered as one of the most important commodities of aquaculture, especially in freshwater fish culture in Asian and some European countries (FAO 2011). Common carp is not classified as a high-priced food; however, it is becoming an essential protein source in human diets. In the last two decades the annual production of common carp increased exponentially and reached more than 3 millions tones in 2010 (FAO 2011). Currently, it represents $14 \%$ of the global freshwater aquaculture production and is mainly cultivated in Asian countries especially in China which accounts for $70 \%$ of the world total production (FAO 2011). The development of common carp industry is challenged by many factors including protection against pathogenic invaders. With respect to this challenge, intestinal barrier functions have moved into the focus of research.

As the first barrier against external invaders from the lumen of the gut, the intestinal epithelium performs a broad range of innate defense mechanisms. The most outer layer, the mucus acts as physical and chemical barrier that protects the epithelium from microbial adherence and colonization, and this layer also might contain antimicrobial substances (Turner 2009). Another physical barrier is formed by the epithelial cells and their apical intercellular junctional structures, the tight junctions (TJs) which prevent microbial internalization (Lal-Nag and Morin, 2009). A major component of TJs is claudin proteins which are not only responsible for allowing ion and water transport but also for building the intestinal physical barrier against foreign antigens (Morita et al., 1999; Lal-Nag and Morin 2009). According to many reports, claudin proteins are regulated during diseases or inflammation processes, and in some cases they become targets of pathogens (Berkes et al., 2003; Prasad et al., 2005; Groschwitz and Hogan 2009; Guttman and Finlay 2009; Schulzke et al., 2009).

Claudin is a multiple genes family. A total of 24 claudin genes were reported from mammals and in particular humans and chimpanzees lack claudin-13 (Lal-Nag and Morin 2009). Fish claudins were at the first time identified in zebrafish, Danio rerio (Kollmar et al., 2001) and then found in many fish species such as Japanese pufferfish, Takifugu rubripes (Loh et al. 2004); spotted green pufferfish, 
Tetraodon nigroviridis (Bagherie-Lachidan et al., 2008); Atlantic salmon, Salmo salar (Tipsmark et al., 2008 ); southern flounder, Paralichthys lethostigma (Tipsmark et al., 2008 ); rainbow trout, Onchorhynchus mykiss (Chasiotis and Kelly, 2011; Sandbichler et al., 2011); and goldfish, Carassius auratus (Chasiotis and Kelly, 2011). However knowledge on fish claudin is still limited. The present work was done in order to molecularly identify claudin protein encoding genes in an important species in freshwater aquaculture, common carp (Cyprinus carpio L.).

\section{Materials and Methods}

\section{Sampling of Intestinal Tissues and RNA Extraction}

After fish was killed, intestinal pieces were collected and placed directly in $1.5 \mathrm{~mL}$ tubes filled with $1 \mathrm{~mL}$ of RNA isolation reagents TriZol (Life Technologies) and then stored at $80^{\circ} \mathrm{C}$ until further use. RNA was extracted according to protocol from the manufacturer. Tissue samples were ground using a Tissue lyser (Qiagen). The resulting suspension was transferred to a new $1.5-\mathrm{mL}$ tube and incubated for 5 minutes at room temperature. After separation with $0.2 \mathrm{~mL}$ chloroform addition, RNA was precipitated from upper aqueous phase with $0.5 \mathrm{~mL}$ of isoprophanol. The RNA pellet was washed twice with $1 \mathrm{~mL}$ of $75 \%$ ethanol and then was dissolved with RNase-free water and heated at $55^{\circ} \mathrm{C}$ for 10 minutes. Finally, quantity and purity of the samples were determined in a Nanodrop spectrophotometer and then the samples were kept at $-80^{\circ} \mathrm{C}$ until use. Samples with a ratio of absorbance $\mathrm{A}_{260 / 280}$ around 2.00 and $\mathrm{A}_{260 / 230}=2.00-2.20$ were accepted as pure RNA samples.

\section{Digestion of Genomic DNA and Construction of cDNA}

Prior to the construction of cDNA a possible contamination with genomic DNA was removed by using RNase-free DNase I (Fermentas) according to manufacturer's protocol. Briefly, a mix of RNA $(1 \mu \mathrm{g}), 1 \mu \mathrm{L}$ of $10 \mathrm{x}$ buffer with $\mathrm{MgCl}_{2}, 2$ units of DNase, and 10 units of ribolock (RNase inhibitor) in DEPC-treated water (up to $10 \mu \mathrm{L}$ of final volume) was incubated for 30 minutes at $37^{\circ} \mathrm{C}$. Subsequently, the DNase was inactivated by adding $1 \mu \mathrm{L}$ of $25 \mathrm{~mm}$ EDTA and incubation at $65^{\circ} \mathrm{C}$ for 10 minutes.

The cDNA was constructed using Maxima Reverse Transcriptase (Fermentas) as described in the manufacturer's protocol. RNA samples were mixed with a mix of $0.25 \mu \mathrm{L}$ oligo dT $(100$ pmol $)$ and $0.25 \mu \mathrm{L}$ random hexamer (100 pmol), $1 \mu \mathrm{L}$ dNTPs (10 mm each), $4 \mu \mathrm{L}$ of $5 x$ RT buffer, $0.5 \mu \mathrm{L}$ ribolock $(20 \mathrm{u}), 1 \mu \mathrm{L}$ Maxima Reverse Transcriptase $(200 \mathrm{u})$ and nuclease-free water (until a total volume of 20 $\mu \mathrm{L}$ ). The mixture was incubated for 10 minutes at $25^{\circ} \mathrm{C}$ followed by 30 minutes at $50^{\circ} \mathrm{C}$. At the end, the reaction was terminated by heating at $85^{\circ} \mathrm{C}$ for 5 minutes. Then the cDNA samples were preserved at $-20^{\circ} \mathrm{C}$ until further analysis. Amplification of $\beta$-actin by using primers which cover intron on few non reverse transcribed samples confirmed no genomic DNA contamination.

\section{Primers Design}

Primers for carp claudin 1 and 2 were designed based on gene specific sequences of other fish species and primers for carp claudin $3^{\mathrm{b}}$, $3^{\mathrm{c}}, 7,11,23$, and $30^{\mathrm{c}}$ were designed on the basis of relevant expressed sequences tags (ESTs) of carp available in gene bank (see Table 1). The primers were designed using the software Primer3 (Rozen and Skaletsky, 1999) and the melting temperature of the primers was calculated using the software of Integrated DNA technologies OligoAnalyzer 3.1 available at eu.idtdna.com. All primers used in the present study are listed in Error! Reference source not found. 
Table 1. Primers used for gene amplification

\begin{tabular}{|c|c|c|c|}
\hline Gene & Name & Sequence $(\ulcorner\rightarrow ` 3)$ & Product size $(\mathrm{bp})$ \\
\hline \multirow[t]{2}{*}{ Claudin-1 } & Cyca_cl1F & tgccaggagaggttcagg & 147 \\
\hline & Cyca_cl1R & cagccacagccactttattc & \\
\hline \multirow[t]{2}{*}{ Claudin-2 } & Cyca_cl2F & gctctggagttgatgggtttc & 189 \\
\hline & Cyca_cl2R & gtaggtctcgcattggaagg & \\
\hline \multirow[t]{2}{*}{ Claudin- $3^{b}$} & Cyca_cl3BF & atatgggagggaatctggatg & 288 \\
\hline & Cyca_cl3BR & gtgagcagaccagcatacag & \\
\hline \multirow[t]{2}{*}{ Claudin $-3^{\mathrm{c}}$} & Cyca_cl3CF & tcacggcacaagtcatctgg & 342 \\
\hline & Cyca_cl3CR & cggtggacagtaaccgggttg & \\
\hline \multirow[t]{2}{*}{ Claudin-7 } & Cyca_cl7F & cccaatggaagatgtctgc & 547 \\
\hline & Cyca_cl7R & aaacgtactccttgctgctg & \\
\hline \multirow[t]{2}{*}{ Claudin-11 } & Cyca_cl11F & cttatcatcgccactgccac & 416 \\
\hline & Cyca_cl11R & tacagggagaagccaaaggac & \\
\hline \multirow[t]{2}{*}{ Claudin-23 } & Cyca_cl23F & agggaatctgggacatctgc & 290 \\
\hline & Cyca_cl23R & gctggtgaggatatgagtgtacc & \\
\hline \multirow[t]{2}{*}{ Claudin- $30^{\mathrm{c}}$} & Cyca_cl30F & atcggcagcaacatcgtcac & 350 \\
\hline & Cyca_cl30R & aacagagggttgtagaagtcc & \\
\hline \multirow[t]{2}{*}{$\beta$-actin } & $\mathrm{BF}$ & ggtatgggacagaaggacagc & 300 \\
\hline & $\mathrm{BR}$ & ggcatacagggacagcac & \\
\hline
\end{tabular}

\section{Claudin Genes Amplification}

For PCR, the standard reaction mix consisted of 1X PCR buffer (Invitrogen), $0.2 \mathrm{~mm}$ of each dNTPs (Fermentas), $1.5 \mathrm{~mm}$ of $\mathrm{MgCl}_{2}$ (Invitrogen), $0.2 \mu \mathrm{m}$ of each primer, 1 unit of Platinum Taq DNA polymerase (Invitrogen), 2 $\mu \mathrm{L}$ of template (cDNA), and in total volume of $20 \mu \mathrm{L}$. The PCR assays were performed in a Mastercycler gradient (Eppendorf). The cycle's program was: initial denaturation, $95^{\circ} \mathrm{C}, 10 \mathrm{~min}$.; denaturation, $95^{\circ} \mathrm{C}, 30 \mathrm{~s}$.; annealing, $55-59^{\circ} \mathrm{C}, 45$ s.; extension, $72^{\circ} \mathrm{C}, 30 \mathrm{s.} ; 40$ cycles; and an additional extension, $72^{\circ} \mathrm{C}, 5 \mathrm{~min}$. Amplification products were confirmed by electrophoresis on ethidium bromide or GelRed pre stained 1.5\% agarose gels and visualized with UV light. The rest of the amplification products were kept at $20^{\circ} \mathrm{C}$ until further use.

\section{Cloning of The Genes}

Amplification products of each gene were cloned into the pGEM-T easy vector (Promega) according to the manufacture's protocol. Briefly, $2 \mu \mathrm{L}$ of PCR product was mixed with $1 \mu \mathrm{L}$ of ligase $(3 \mathrm{U} / \mu \mathrm{L}), 0.5 \mu \mathrm{L}$ vector $(25 \mathrm{ng})$, and $5 \mu \mathrm{L}$ of $5 \mathrm{x}$ ligation buffer in a total volume of $10 \mu \mathrm{L}$. After incubation at $4{ }^{\circ} \mathrm{C}$ over night, $2 \mu \mathrm{L}$ of the ligation product was mixed with $25 \mu \mathrm{L}$ of Escherichia coli JM109 High-Efficiency Competent Cells (Promega) and placed on ice for 20 minutes. The mix then was heat-shocked at $42^{\circ} \mathrm{C}$ for 45 seconds and placed back on ice for 2 minutes. After adding of 970 $\mu \mathrm{L}$ of LBB and incubated at $37^{\circ} \mathrm{C}$ for 2 hours, 50 $\mu \mathrm{L}$ of the concentrated bacterial suspension was poured on LB/ampicillin/IPTG/X-gal plates. White colonies were collected, cultured in LBB for 16-18 hours and then the recombinant plasmid was isolated.

The recombinant plasmid was isolated using the GeneJet plasmid miniprep kit (Fermentas) according to the protocol from the manufacturer. Briefly, pelleted cells were resuspended in $250 \mu \mathrm{L}$ of resuspension solution and lysed using $250 \mu \mathrm{L}$ of lysis solution. After the process was terminated using $350 \mu \mathrm{L}$ of neutralization solution, the samples were centrifugated at more than $12000 \mathrm{x}$ g for 5 minutes and the supernatant was transferred to a separation column. After two washing steps, the plasmid samples were eluted and stored at $-20^{\circ} \mathrm{C}$ until further use.

The presence of a DNA insert in the recombinant plasmid was confirmed by an endonuclease digestion assay. Four $\mu \mathrm{L}$ of every plasmid were mixed with $0.5 \mu \mathrm{L}$ of $E c o \mathrm{R} 1$ and 1 $\mu \mathrm{L}$ of buffer in a total volume of $10 \mu \mathrm{L}$. After incubation at $37^{\circ} \mathrm{C}$ for 2 hours, the DNA plasmid and the DNA insert were separated on a $1.5 \%$ agarose gel pre stained with GelRed (Biotium) in $100 \mathrm{mV}$ for 30 minutes and visualized under UV light.

\section{Sequencing and Sequence Analysis}

Recombinant plasmids were directly sequenced (LGC Genomicy GmbH, Germany). Nucleotide sequences of carp claudin encoding genes were confirmed as part of targeted genes using a BLASTn analysis (Altschul et al., 1990) 
and translated in silico into an amino acid sequence with a DNA translation tool available online at www.expasy.org (Gasteiger et al., 2003). Further confirmation of carp claudins was performed based on local and global models Pfam HMMs as motif sources by MyHits motif scan analysis (Pagni et al., 2004; Pagni et al., 2007) available at www.myhits.isb-sib.ch. Transmembrane domains of claudins were predicted by SOSUI (Hirokawa et al., 1998; Mitaku and Hirokawa 1999; Mitaku et al., 2002) available at bp.nuap.nagoya-u.ac.jp. Protein motifs of carp claudins were compared with those of relevant animals by means of multiple sequence alignment analysis using ClustalW (Larkin et al., 2007) in default settings (www.ebi.ac.uk). The Phylogenetic relationship of carp claudin genes with appropriate genes of other fish were analyzed by following steps and methods: alignment, MUSCLE; curation, Gblock; phylogeny, phyML; and tree rendering, treeDyn at www.phylogeny.fr (Guindon and Gascuel 2003; Edgar 2004; Anisimova and Gascuel 2006; Dereeper et al., 2008; Dereeper et al., 2010).

\section{Results}

From common carp intestinal tissues, partial fragments of eight carp claudin encoding genes were successfully amplified, cloned, sequenced, and confirmed as parts of claudin encoding genes by using BLASTn analysis (www.ncbi.nlm.nih.gov) and/or by motif scan analysis (www.myhits.isb-sib.ch). Two claudin genes, claudin-1 and -2 were amplified from cDNA of carp by using primers designed on the basis of the same genes of other animals. Sequences of the other six claudin genes of carp: claudin $-3^{\mathrm{b}},-3^{\mathrm{c}},-7,-11,-23$, and -30 were identified by using primers designed on the basis of claudin-like ESTs from carp, which were obtained by performing BLASTn analysis of all zebrafish and pufferfish claudins on the EST database available in the GenBank.

A phylogenetic tree, constructed on the basis of the nucleotide sequences of claudins and shown in Figure 1, describes the relationship of the eight carp claudin genes from this study with other claudin genes identified in teleost species. According to the consensus phylogenetic tree of claudin proteins (Loh et al., 2004), six carp claudin genes were assigned to the first gene cluster and two carp claudin genes were assigned to the second gene cluster. On the basis of the phylogenetic analysis and according to the claudin nomenclature proposed for Japanese pufferfish claudins (Loh et al., 2004), names for carp claudins were considered. In cases when only one isoform was identified, the carp claudin gene was named according to the main name of the pufferfish claudin and not to the name for an isoform. Six carp claudin genes sequences were deposited in the GenBank (accession number JQ767156- JQ767160). Only fragments of less than 200 bp were obtained from claudin- 1 and claudin-2 and therefore the sequences of these two genes could not be deposited in the GenBank because of an internal policy of this data base.

Typical molecular properties of the multiple genes family of tight junction protein claudins include two cytoplasmic tails, four transmembrane (TM) domains, one intracellular loop (IL), two extracellular loops (ELs), and two highly conserved cysteine residues in the first extracellular part (Lal-Nag and Morin 2009). In order to confirm identified genes in this work, partial protein sequences of carp claudin genes were in silico transcribed, their molecular motifs were predicted, and the level of identity among other fish claudins was analysed. A fragment of carp claudin-1 consists of an incomplete domain of TM-2, IL, and few amino acid residues of TM3 (Figure 2). Parts of TM-1 and the extracellular loop 1 (EL-1) of carp claudin-2 were identified (Figure 3). The identified fragment of carp claudin-3b showed parts of EL-1, TM-2, IL, and TM-3 (Figure 4). Features of EL-1, TM-2, IL, TM-3, and EL-2 were determined from a partial protein sequence of claudin-3c (Figure 5). All properties of claudin-7 except of the amino-tail, TM-1, and few residues of EL-1 were identified in carp (Figure 6). A fragment that is starting from EL-1 until carboxy-tail of carp claudin-11 was reported (Figure 7). Fragments consisting of EL-1, TM-2, IL, and TM-3 were identified as parts of carp claudin-23 (Figure 8), and claudin30 (Figure 9). In comparison to the same genes of other fish species, claudin genes of carp showed different level of identity. For examples; carp claudin-30 was $93 \%$ identical to claudin-b of goldfish (Figure 9) and carp claudin-11 was 92\% similar with claudin- $11^{\text {a }}$ of zebrafish (Figure 7). In contrast, carp claudin-1 was only $63 \%$ and $60 \%$ identical with the genes of zebrafish and Japanese pufferfish, respectively (Figure 2) and the sequence of carp claudin $-3^{\mathrm{b}}$ had a low identity to claudin $-3^{\mathrm{b}}$ of the Japanese pufferfish or claudin-3 of Atlantic salmon with $62 \%$ and $67 \%$, respectively (Figure 4). 


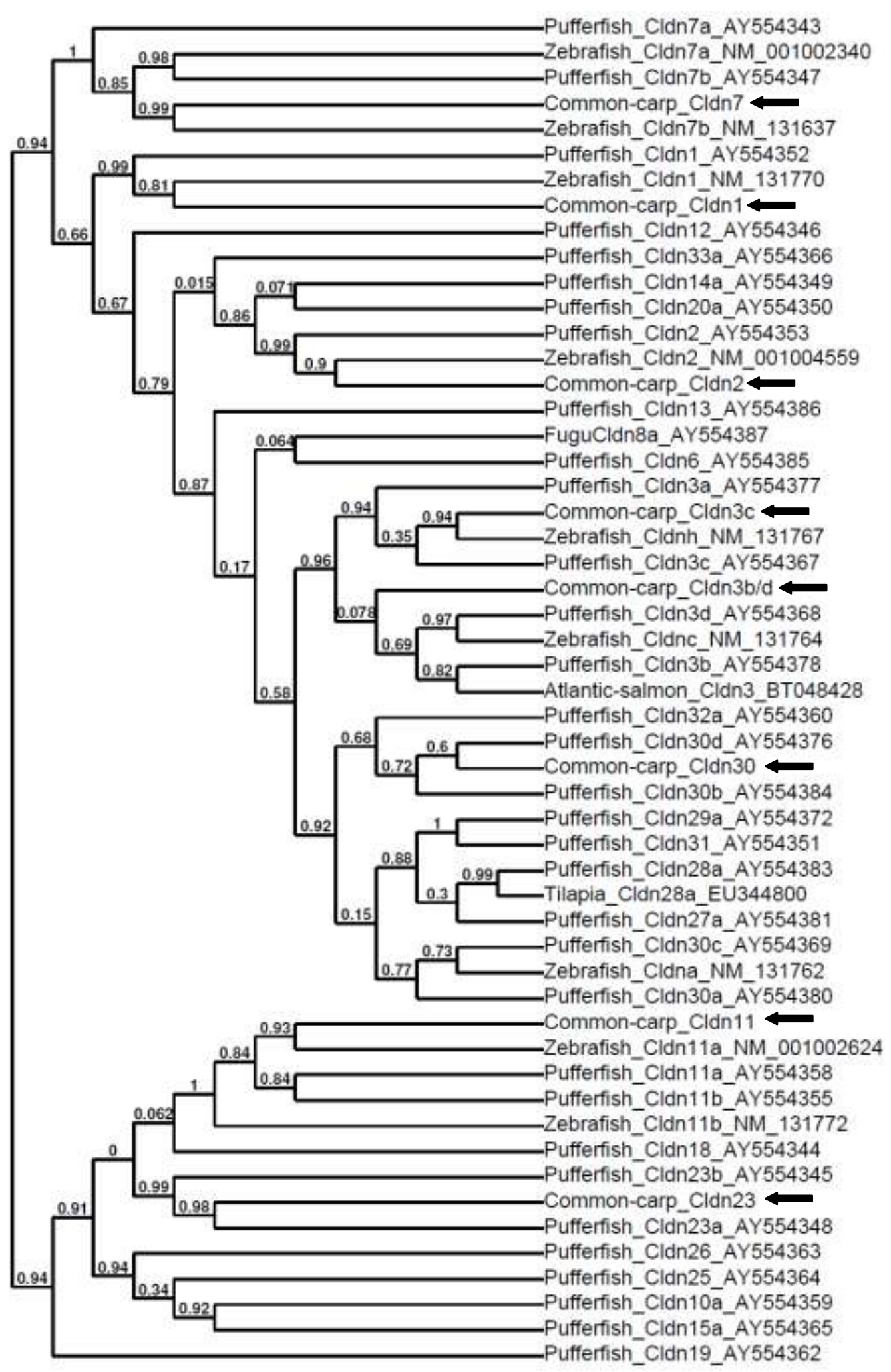

Figure. 1. Unrooted cladogram of fish claudin genes.

The phylogenetic analysis included carp claudin-1, -2, $-3^{\mathrm{b}}$ (JQ767156), $-3^{\mathrm{c}}$ (JQ767157), -7 (JQ767155), -11 (JQ767158), -23 (JQ767159), and -30 (JQ767160) encoding genes, and its relevant genes from pufferfish (Takifugu rubripes), zebrafish (Danio rerio), Atlantic salmon (Salmo salar), and tilapia (Oreochromis mosambicus). The carp claudin gene sequences were obtained from this study and the other sequences were retrieved from GenBank. The accession numbers are mentioned in the leaves names. The carp claudin genes are indicated by the arrows.

\section{AQUACULTURA INDONESIANA}




\section{Zebrafishcldn1 Pufferfishcldn1 Carpclinn 1}

\section{Zebrafishcldn1 Pufferfishcldn1 Carpcldn1}

Zebrafishcldn1
PufferfishCldn1
Carpcldn1

Zebrafishcldn1 Pufferfishcldn1 Carpcldn1
TM-1 EL-1 $\vee$ MAHAGLQMLGYCLGFLGLLGLIASTAMAEWKMSSYAGDNITAQAOYEGLWOSCVSOSTG 60 MANAGIQLLGFILAFLGLIGTIASTIMVEWKASSYAGDNIITAQAMYEGLWKSCVSQSTG 60
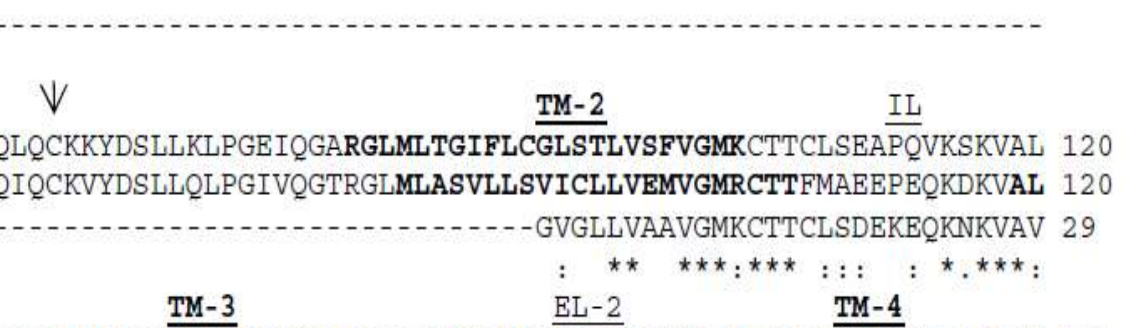

AGGVLFITGGLFALIATSWYGEKIRQKFFDPFTPTNARYEFGKALYVGWGSSALSIIGGS 180 AGGVIFIIAGLLALVGTSWYGHRIAREFYDPFTPTNSRYEFGSALYVGWGAACLTLIGGG 180

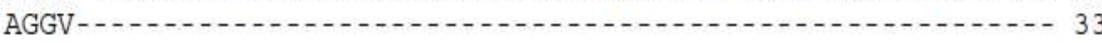

****

LLCCICGSEASEK-PSYPPARAAGRPGTDRV 210

FLCCSCPKKGSQKSPRYPPTRSSGPQGKDYV 211

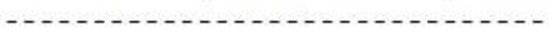

\begin{tabular}{|c|c|c|}
\hline SeqA: Name (length) & SeqB: Name (length) & Score \\
\hline CarpCldn1 (33 aa) & ZebrafishCldn1 (210 aa) & 63.0 \\
\hline CarpCldn1 (33 aa) & PufferfishCldn1 (211 aa) & 60.0 \\
\hline ZebrafishCldn1 (210 aa) & PufferfishCldn1 (211 aa) & 65.0 \\
\hline
\end{tabular}

Figure 2. Multiple alignment of deduced protein sequences of fish claudin-1 genes (A) and their pairwise scores (B). The analysis included claudin-1 genes of common carp (Cyprinus carpio; present work), zebrafish (Danio rerio; accession number: NM_131770), and pufferfish (Takifugu rubripes; accession number: AY554352). Domains of four transmembranes (TM, bold letters), two extracellular loops (EL), and an intracellular loop (IL) are indicated. Arrows show two highly conserved cysteine residues.

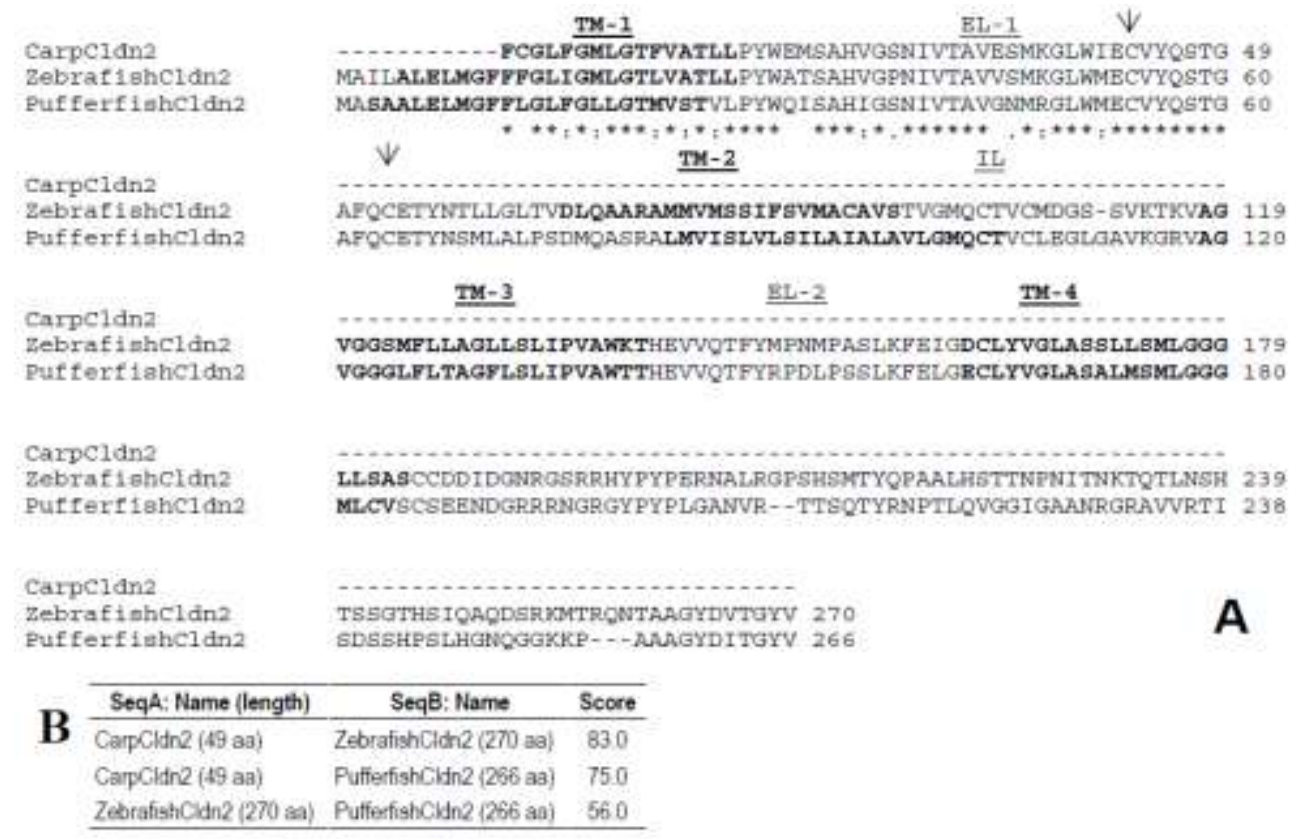

Figure 3. Multiple alignment of deduced protein sequences of fish claudin-2 genes (A) and their pairwise scores (B). The analysis included claudin-2 genes of common carp (Cyprinus carpio; present work), zebrafish (Danio rerio; accession number: NM_001004559), and pufferfish (Takifugu rubripes; accession number: AY554353). Domains of four transmembranes (TM, bold letters), two extracellular loops (EL), and an intracellular loop (IL) are indicated. Arrows show two highly conserved cysteine residues. 


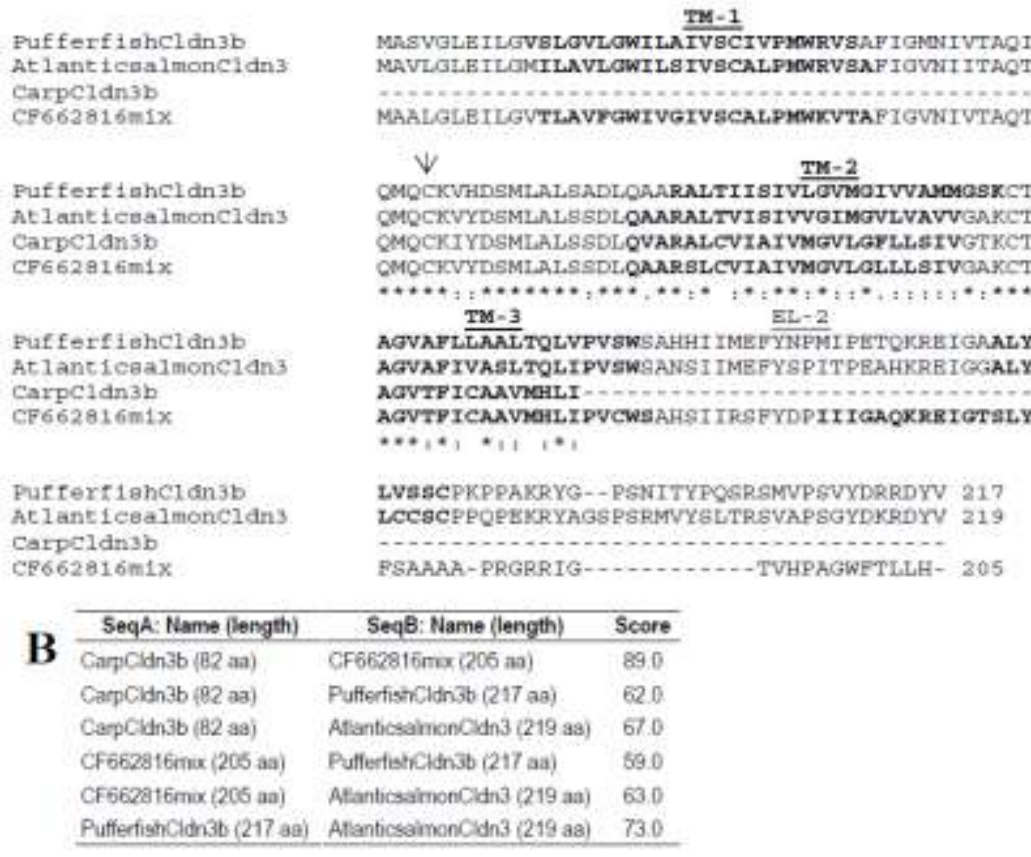

ELL. -1 V

TWESTMNCVVOSTG 60

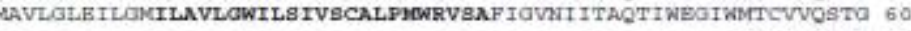
W***

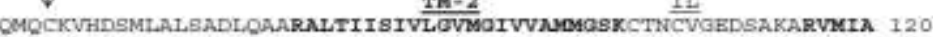
(120

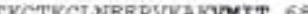

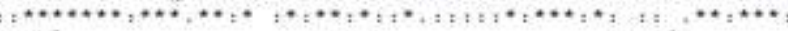
TM-4

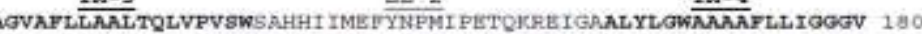
AGVAPTVASLTQLIPVSWSANSI IMEFYSPITPEAHKRE IGGALYLGWAAAAYLLIGGCI 180 PSVTTYPGSR SMUPGXRRDYV 217

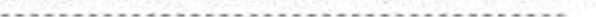

A

Figure 4. Multiple alignment of deduced protein sequences of fish claudin- $3^{\mathrm{b}}$ genes (A) and their pairwise scores (B). The analysis included carp EST (CF662816; a mix library of skeletal white muscle, cardiac muscle, brain, gill, kidney and intestinal mucosa tissues) and claudin $-3^{\mathrm{b}}$ genes of common carp (Cyprinus carpio; present work; accession number: JQ767156), Atlantic salmon (Salmo salar; accession number: BT048428) and pufferfish (Takifugu rubripes; accession number: AY554378). Domains of four transmembrane (TM, bold letters), two extracellular loops (EL), and an intracellular loop (IL) are indicated. Arrows show two highly conserved cysteine residues.

\begin{tabular}{|c|c|c|c|}
\hline \multicolumn{2}{|c|}{$\operatorname{carpclan} 3 c$} & \multicolumn{2}{|c|}{ 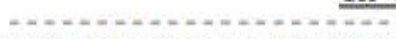 } \\
\hline \multicolumn{2}{|c|}{ EC393103akin } & \multicolumn{2}{|c|}{ MSMGLELGGIALGIIGWIISIV } \\
\hline \multicolumn{2}{|c|}{ zebrafishclanh } & \multicolumn{2}{|c|}{ MSMGLEIGGIALGIIGWIISIV } \\
\hline \multicolumn{2}{|c|}{ Pufferfishclan $3 \mathrm{C}$} & \multicolumn{2}{|c|}{ MSMGMEIVGIALGVLGFIITIV } \\
\hline \multirow{4}{*}{\multicolumn{2}{|c|}{$\begin{array}{l}\text { Carpclan } 3 \mathrm{c} \\
\text { Ec393103akin } \\
\text { Zebrafishclanh } \\
\text { Puffertishclan } 3 \mathrm{C}\end{array}$}} & \multicolumn{2}{|c|}{ 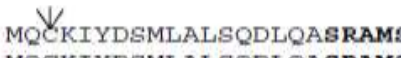 } \\
\hline & & \multicolumn{2}{|c|}{ MQCKIYDSMLALSQDLQASRAM } \\
\hline & & \multicolumn{2}{|c|}{ MQCKVYDSMLALGQDLQASRAM } \\
\hline & & \multicolumn{2}{|l|}{ 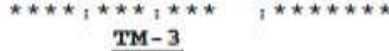 } \\
\hline \multicolumn{2}{|c|}{ Carpcld } & \multicolumn{2}{|c|}{ GVMFII AGILELIPVAWVANQT } \\
\hline \multicolumn{2}{|c|}{ EC393103 $\mathrm{kkin}$} & \multirow{2}{*}{\multicolumn{2}{|c|}{$\begin{array}{l}\text { GVMFIIAGILELIPVAWVANQT } \\
\text { GIMFIIAGILDLIPSAWVANQI }\end{array}$}} \\
\hline \multirow{3}{*}{\multicolumn{2}{|c|}{$\begin{array}{l}\text { Zebraflahclanh } \\
\text { Pufferfiahclan } 3 \mathrm{c}\end{array}$}} & & \\
\hline & & \multirow{2}{*}{\multicolumn{2}{|c|}{ GIFFILGGVLVLIPVSWTAHV }} \\
\hline & & & \\
\hline \multirow{4}{*}{\multicolumn{2}{|c|}{$\begin{array}{l}\text { Carpclansc } \\
\text { Ec393io3skin } \\
\text { Zebrafiehclanh } \\
\text { Pufferfishclan } 3 \mathrm{C}\end{array}$}} & \multicolumn{2}{|c|}{ 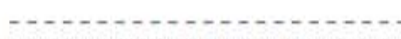 } \\
\hline & & \multicolumn{2}{|c|}{ CCTCPPREKKYKPPRMOYSAPR } \\
\hline & & \multirow{2}{*}{\multicolumn{2}{|c|}{ CCTCPPKEKKYKPARMGYSAPR }} \\
\hline & & & \\
\hline \multirow{7}{*}{ B } & SeqA: Name (length) & SeqB: Name (length) & Score \\
\hline & CarpCldn3c (100 aa) & EC393103skin (208 aa) & 98.0 \\
\hline & CarpCldn3c (100 aa) & PufferfishCldn3C (216 aa) & 68.0 \\
\hline & CarpCldn3c (100 aa) & ZebrafishCldnh (214 aa) & 840 \\
\hline & EC393103skin (208 aa) & PufferfishCldn3C (216 aa) & 71.0 \\
\hline & EC393103skin (208 aa) & ZebrafishCldnh (214 aa) & 88.0 \\
\hline & PufferfiahCldn3C (216 aa) & ZebrafishCldnh (214 aa) & 75,0 \\
\hline
\end{tabular}

Figure 5. Multiple alignment of deduced protein sequences of fish claudin- $3^{\mathrm{c}}$ genes (A) and their pairwise scores (B). The analysis included carp EST (EC393103, skin library) and claudin-3 $3^{\mathrm{c}}$ genes of carp (Cyprinus carpio; present work; accession number: JQ767157), zebrafish (Danio rerio; accession number: NM_131767), and pufferfish (Takifugu rubripes; accession number: AY554367). Domains of Four transmembrane (TM, bold letters), two extracellular loops (EL), and an intracellular loop (IL) are indicated. Arrows show two highly conserved cysteine residues. 


\begin{tabular}{|c|c|c|c|}
\hline \multirow{2}{*}{\multicolumn{2}{|c|}{ Carpclan? }} & \multicolumn{2}{|l|}{$T M-1$} \\
\hline & & \multirow{2}{*}{\multicolumn{2}{|c|}{ MANYCLQLLGFTLSLLLIGLI }} \\
\hline \multicolumn{2}{|c|}{ EC393792akin } & & \\
\hline \multicolumn{2}{|c|}{ zebrafiah>b } & \multicolumn{2}{|c|}{ MAHXCLLLLGFTLALLGLIOLI } \\
\hline \multirow{2}{*}{\multicolumn{2}{|c|}{ Pufferfiahclantb }} & \multicolumn{2}{|l|}{ MAUSGMOLLGFFMAI } \\
\hline & & \multicolumn{2}{|l|}{$\forall$} \\
\hline \multicolumn{2}{|c|}{ Carpclan 7} & \multicolumn{2}{|c|}{ QMQCKVYDSILQLDSILOATRA } \\
\hline \multicolumn{2}{|c|}{ EC393792akin } & \multicolumn{2}{|c|}{ QMQCKVYDSILQLDSSLQATRA } \\
\hline \multicolumn{2}{|c|}{ Zebrafiuhtb } & \multicolumn{2}{|c|}{ QQQCKVYDSVLOLDSALOATRA } \\
\hline \multicolumn{2}{|c|}{ Purfertiohciantb } & \multicolumn{2}{|c|}{$\begin{array}{c}\text { QLQCKIYDSILQLDSSLOATRA } \\
\cdots, \cdots, \cdots, \cdots, \cdots \\
\text { TM-3 }\end{array}$} \\
\hline \multicolumn{2}{|c|}{ Carpcian7 } & \multicolumn{2}{|c|}{ TGGIVLIVAALCSIVACGWFTV } \\
\hline \multicolumn{2}{|c|}{ EC3937928k1n } & \multicolumn{2}{|c|}{ TGGIVLIVGALCS IVACGWYTN } \\
\hline \multirow{3}{*}{\multicolumn{2}{|c|}{$\begin{array}{l}\text { Zebraf } 1 \mathrm{ah} 7 \mathrm{~b} \\
\text { Pufferfiahclantb }\end{array}$}} & \multirow{3}{*}{\multicolumn{2}{|c|}{ 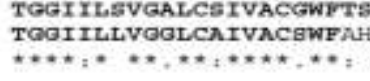 }} \\
\hline & & & \\
\hline & & & \\
\hline \multirow{5}{*}{\multicolumn{2}{|c|}{$\begin{array}{l}\text { Carpcian7 } \\
\text { Ec393792akin } \\
\text { zebrafiah7b } \\
\text { Purferfiehclan7b }\end{array}$}} & \multirow{2}{*}{\multicolumn{2}{|c|}{$\begin{array}{l}\text { ML_AASCPKGKSSPRYP- - KSSR } \\
\text { MLAAASCPKGKSSPRYP - KSSR }\end{array}$}} \\
\hline & & & \\
\hline & & \multicolumn{2}{|c|}{ MLASSCSKGQSEPNYP - - KSSR } \\
\hline & & \multicolumn{2}{|c|}{ MIAAASCPRANYCHLPKYPPTASSR } \\
\hline & & $\cdots+\cdots, 1,1, *,+*$ & \\
\hline \multirow{7}{*}{ B } & SeqA: Name (length) & SeqB: Name (length) & Score \\
\hline & CarpCidn7 (171 aa) & EC393792skin (209 aa) & 990 \\
\hline & CarpCidn7 (171 aa) & PufferfighCidn7b (213 as) & 720 \\
\hline & CarpCldn7 (171 aa) & Zebrafish7b (215 as) & 90.0 \\
\hline & EC393792akin (209 aa) & PufterfahCidn $7 \mathrm{~b}$ ( $213 \mathrm{aa})$ & 74.0 \\
\hline & EC3937929kin (209 aa) & Zebrafish $7 \mathrm{~b}(215 \mathrm{aa})$ & 91.0 \\
\hline & PufferfstyCidn7b (213 aa) & Zebrafish $7 \mathrm{~b}(215 \mathrm{as})$ & 690 \\
\hline
\end{tabular}

Figure 6. Multiple alignment of deduced protein sequences of fish claudin-7 genes (A) and their pairwise scores (B). The analysis included carp EST (EC393792, skin library) and claudin-7 genes of common carp (Cyprinus carpio; present work; accession number: JQ767155), zebrafish (Danio rerio; accession number: NM_131637), and pufferfish (Takifugu rubripes; accession number: AY554347). Domains of four transmembrane (TM, bold letters), two extracellular loops (EL), and an intracellular loop (IL) are indicated. Arrows show two highly conserved cysteine residues.

\begin{tabular}{|c|c|c|c|}
\hline \multirow{2}{*}{\multicolumn{2}{|c|}{ Carpcldnyt }} & \multicolumn{2}{|c|}{$T M-1$} \\
\hline & Carpcidnil & \multirow{2}{*}{\multicolumn{2}{|c|}{ MANTCLQFTGFVRBFLOWIGLII }} \\
\hline \multicolumn{2}{|c|}{ DW7224 } & & \\
\hline \multirow{2}{*}{\multicolumn{2}{|c|}{$\begin{array}{l}\text { Zebrafiahclanila } \\
\text { Putferfiahclanila }\end{array}$}} & \multicolumn{2}{|c|}{ MANTCLOFTGIVNSPLOWIGLIV } \\
\hline & & \multicolumn{2}{|c|}{ MANGCLQLGGFLVSCLGWMGVVI } \\
\hline & \multicolumn{2}{|l|}{$\underline{T M-2}$} \\
\hline & & \multicolumn{2}{|c|}{ ALYHCITLTQILBLPAYTOTSRA } \\
\hline \multicolumn{2}{|c|}{ DW722473tea } & \multicolumn{2}{|c|}{ ALYHCITLTQILBLPAYIOTSRA } \\
\hline \multicolumn{2}{|c|}{ Zebre } & \multicolumn{2}{|c|}{ ALYHCITLTQILELPAYIQTSRA } \\
\hline \multirow{2}{*}{\multicolumn{2}{|c|}{ Pufferfiehelanila }} & \multirow{2}{*}{\multicolumn{2}{|c|}{ GLYHCVSLTOILDLPAYICTTRA }} \\
\hline & & & \\
\hline \multicolumn{2}{|c|}{ Carpclant 1} & \multicolumn{2}{|c|}{ VLGGTIILLTAPCGVVSTVWPPI } \\
\hline \multicolumn{2}{|c|}{ DW722473teat Is } & \multicolumn{2}{|c|}{ VLOGTIMLLTAFCDIVGTVWFPI } \\
\hline \multirow{3}{*}{\multicolumn{2}{|c|}{$\begin{array}{l}\text { Zebrafiahclanila } \\
\text { Putferfiehclanila }\end{array}$}} & \multirow{2}{*}{\multicolumn{2}{|c|}{$\begin{array}{l}\text { VLGGILIILTAFCOTVSTVWFPI } \\
\text { VLG-RSRGSHRLCSLVSTVWFPI }\end{array}$}} \\
\hline & & & \\
\hline & & \multicolumn{2}{|l|}{$* \star \star$} \\
\hline \multicolumn{2}{|c|}{ Carpcldnil } & \multicolumn{2}{|c|}{ (1) } \\
\hline \multirow{2}{*}{\multicolumn{2}{|c|}{$\begin{array}{l}\text { DW722473teat1a } \\
\text { Zebrafiahcianila } \\
\text { Pufferfiahclanila }\end{array}$}} & \multicolumn{2}{|c|}{ D-SPATYTBHARFYYSRQGPAHT } \\
\hline & & \multicolumn{2}{|c|}{ DSLPRSEQDEDRFYYSKQGGGNA } \\
\hline \multirow{7}{*}{ B } & SeqA: Name (length) & SeqB: Name (length) & Score \\
\hline & CarpCidn 11 (126 aa) & DW722473lestis $(163$ an) & 960 \\
\hline & CarpCidnt1 (126 aa) & Pufferfshcidnt ta (216 as) & 650 \\
\hline & CarpCidn11 (126 as) & Zebrafishculn11a (215 as) & 92.0 \\
\hline & DW7722473tes69 (163 as) & Putterfaholdntta (216aa) & 65.0 \\
\hline & DAV722473testis (163 aa) & ZebrafishCldn $11 \mathrm{a}(215 \mathrm{aa})$ & 890 \\
\hline & PuffertishCidn 1 1a (216 as) & ZebrafishCldn11a (215 aa) & 66.0 \\
\hline
\end{tabular}

Figure 7. Multiple alignment of deduced protein sequences of fish claudin-11 genes (A) and their pairwise scores (B).

The analysis included carp EST (DW722473, testis library) and claudin-11 genes of common carp (Cyprinus carpio; present work; accession number JQ767158), zebrafish (Danio rerio; accession number: NM_001002624), and pufferfish (Takifugu rubripes; accession number: AY554358). Domains of four transmembrane (TM, bold letters), two extracellular loops (EL), and an intracellular loop (IL) are indicated. Arrows show two highly conserved cysteine residues. 


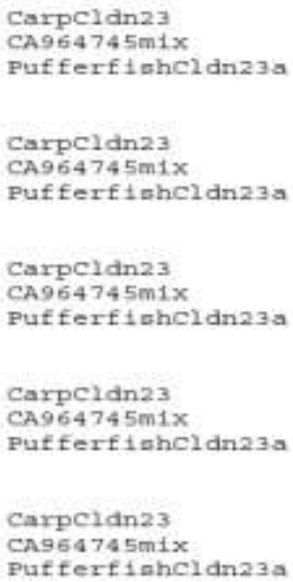

$T \mathrm{TM}-1$

EL-1

TE 2

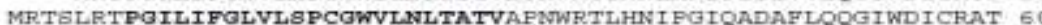
$\forall$

$$
\mathrm{TP}-2
$$
TTSRBQLCNOQGNDQ IYFNSO I IPINKGMOVVABLIVTLLOLALATPGVRCWKCDRPEWILA 62 TTSRSOLCNOOGNDO I YFNSO I IDINKGMEVABL, IVTLLGLALATPOVRCWFDRPRWILA II6 BTEBRABCGLO- DTTYFNHE I I PVAQGLMVA SLVVTI I GL IVA IPGVRCWRDNENWTVA 11

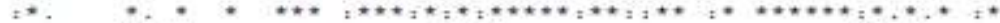
$\mathrm{TM}-3$
$\mathrm{BL}-2$ A SLGGLIIFCSGALTIIPIAWYTH:ILTI GLGGLLIFI SGVFTIIPISWYTHLINE IPSS -..... BPLTDVRVGYCIVLGFIGGIFEI 172 , .........., ....

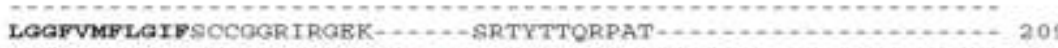
LAGFVMF IOICR CCGGMNRGERVEEVMEERYKOQKPEPRRFEVPGLNRARSSFASEVPY 232

10,

SKDSLDDDVSFPRAKEPAARETNTTVSGRPYDADL 267

B \begin{tabular}{llc}
\hline SeqA: Name (length) & SeqB: Name (length) & Score \\
\hline CarpCidn23 (81 aa) & CA964745mix 1209 aa) & 100.0 \\
CarpCidn23 (81 aa) & PutferfishCidn23a (267 as) & 53.0 \\
CA964745mix (209 aa) & PutferfishCidn23a (267 aa) & 56.0 \\
\hline
\end{tabular}

Figure 8. Multiple alignment of deduced protein sequences of fish claudin-23 genes (A) and their pairwise scores (B). The analysis included carp EST (CA964745, a mix library of skeletal white muscle, cardiac muscle, brain, gill, kidney and intestinal mucosa tissues) and claudin-23 genes of common carp (Cyprinus carpio; present work; accession number: JQ767159), and pufferfish (Takifugu rubripes; accession number: AY554348). Domains of four transmembrane (TM, bold letters), two extracellular loops (EL), and an intracellular loop (IL) are indicated. Arrows show two highly conserved cysteine residues.

\begin{tabular}{|c|c|c|c|}
\hline \multicolumn{2}{|c|}{ Carpcian 30} & \multicolumn{2}{|c|}{ …................... } \\
\hline \multicolumn{2}{|c|}{ EC394291akin } & \multirow{2}{*}{\multicolumn{2}{|c|}{ MVBAGLQLLOTALAIIOWIGVI }} \\
\hline \multicolumn{2}{|c|}{ doldelahelanb } & & \\
\hline \multirow{2}{*}{\multicolumn{2}{|c|}{$\begin{array}{l}\text { Zebrafiahclanb } \\
\text { Pufferfighclansoc }\end{array}$}} & \multicolumn{2}{|c|}{ MASTCLONLGIALAIFGWIGVI } \\
\hline & & \multicolumn{2}{|c|}{ MVSTGYOMLGARLGTVGNI GA] } \\
\hline \multirow{2}{*}{\multicolumn{2}{|c|}{ Carnc }} & \multicolumn{2}{|l|}{$\Downarrow$} \\
\hline & 30 & \multirow{2}{*}{\multicolumn{2}{|c|}{ CMQCXVYDEMLALSIDLQAARA }} \\
\hline \multicolumn{2}{|c|}{ EC3942910kin } & & \\
\hline \multicolumn{2}{|c|}{ Goldt 1 ahc } & \multicolumn{2}{|c|}{ 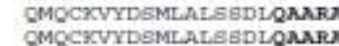 } \\
\hline \multirow{2}{*}{\multicolumn{2}{|c|}{$\begin{array}{l}\text { Zebratiahcidnb } \\
\text { Puttertiahcldn } 30 \text { c }\end{array}$}} & \multicolumn{2}{|c|}{ CHOCSCYYDEMLALSSDIOANU } \\
\hline & & \multicolumn{2}{|c|}{ OMOCKYYDSMLALOSDLQNAFU } \\
\hline \multicolumn{2}{|c|}{ but a } & \multicolumn{2}{|c|}{ 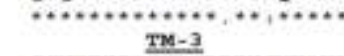 } \\
\hline \multirow{2}{*}{\multicolumn{2}{|c|}{ BC3942919k1n }} & \multicolumn{2}{|c|}{ SGVIPIIAGVIFLIPVCNTAS } \\
\hline & & \multirow{2}{*}{\multicolumn{2}{|c|}{ SGVIYIIAGVLCLIPVCNTAUT }} \\
\hline \multicolumn{2}{|c|}{ Goldarlahclanx } & AGVIPIIAGVLCLI PVCWTANV & \\
\hline \multirow{3}{*}{\multicolumn{2}{|c|}{$\begin{array}{l}\text { Zehrafiohcldnib } \\
\text { Pufferfiehclanjoc }\end{array}$}} & \multirow{3}{*}{\multicolumn{2}{|c|}{ 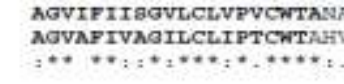 }} \\
\hline & & & \\
\hline & & & \\
\hline \multicolumn{2}{|r|}{ anso } & \multirow{2}{*}{\multicolumn{2}{|c|}{ LCCACPPKDDTOKYTAKYSAD }} \\
\hline \multicolumn{2}{|c|}{ EC394291akin } & & \\
\hline & & \multicolumn{2}{|c|}{ tcogc $\ldots . . . . . . . .}$. \\
\hline Zeb: & afiohcidnb & LCCHCDEKSDSOKYTA & \\
\hline & ertiahcidin $30 \mathrm{e}$ & LCCNCDKK-DKLSYTA & $2 \mathrm{YN}$ \\
\hline & SeqA: Wame (length) & Seq8: Name (length) & Scor \\
\hline & Capcidn30 (10t as) & EC394291skin (214 ae) & 960 \\
\hline & Capcidn30 (10t as) & PufferfishCidn30c (214 as $\}$ & 75.0 \\
\hline & CarpClanjou (10t aa) & GoldfishCldnb (169 aa) & 930 \\
\hline & Capclin30 (101 aa) & Zebreftshicladnb (215.as) & 85.0 \\
\hline & EC394291skn (214 asa) & Puffe-fistcldn30c (214 as) & 71.0 \\
\hline & EC394291skn (214 sa) & GoidflishCldnb (169 as) & 91.0 \\
\hline & EC394291shan (214 as) & Zobreafehicidab (215 aa) & 820 \\
\hline & PudforfishCidna0c (214 aa) & Goidfiahcidnb ( 169 aa) & 76.0 \\
\hline & Putharfshoidn30c (214 aa) & Zebratshoinhb (215 as) & 680 \\
\hline & GoldfishCidrb (169 as) & Zebrafshoddab (215 a3) & 85.1 \\
\hline
\end{tabular}

Figure 9. Multiple alignment of deduced protein sequences of fish claudin-30 genes (A) and their pairwise scores (B). The analysis included carp EST (EC394291, skin library) and claudin-30 genes of common carp (Cyprinus carpio; present work; accession number: JQ767160), zebrafish (Danio rerio; accession number: AF359426), Gold fish (Carassius auratus; accession number: HQ656008) and pufferfish (Takifugu rubripes; accession number: AY554369). Domains of four transmembrane (TM, bold letters), two extracellular loops (EL), and an intracellular loop (IL) are indicated. Arrows show two highly conserved cysteine residues. 


\section{Discussion}

Correspond to the current state of typical profiles of members in claudin multiple genes family (Lal-Nag and Morin, 2009) fish claudins genes are characterized by four transmembrane helices and two extracellular loops (ELs). The two extracellular structures of claudins allow them to build intercellular junctional structures which mainly involve the second EL and mediate selectively barrier permeability functions of TJs that are mainly facilitated by the first EL (Van Itallie and Anderson, 2004, 2006). Roles of the first extracellular domain in size and charge paracellular selectivity have been at least described in claudin-2, -4 (Colegio et al., 2003), 5 (Wen et al., 2004), and -7 (Alexandre et al., 2007). Furthermore two conserved cysteine residues that were predicted to form intramolecular disulfide bond for protein stabilization (Wen et al., 2004; Angelow et al., 2008; Lal-Nag and Morin 2009) are consistently present in EL-1 domains of fish claudins.

In piscine studies, the first identification of claudin genes was made in Zebrafish (Kollmar et al., 2001). Thereafter, molecules from the claudin gene family were found in other fishes (Loh et al., 2004; Bagherie-Lachidan et al., 2008; Tipsmark et al., 2008 ; Tipsmark et al., 2008b; Chasiotis and Kelly 2011; Sandbichler et al., 2011). Interestingly, in the Japanese pufferfish the claudin gene family comprises a higher number of members (56) than in mammals and some of them represent fish specific claudin genes (Loh et al., 2004). In the present study, eight claudin genes, claudin $-1,-2,-3^{\mathrm{b}},-3^{\mathrm{c}},-7,-11$, -23 , and -30 , were identified from common carp. In gene expression studies, transcript level of some claudin genes in common carp was modulated under Koi Herpesvirus (KHV) infection (Adamek et al., 2013, Syakuri et al., 2013) and after feeding beta-glucan and Aeromonas hydrophila intubation (Syakuri et al., 2014). Therefore further studies are needed and modulation of the genes expression could be considered as a part of diseases protection strategies in common carp cultivation.

\section{Acknowledgements}

This work was supported by the European Community's Seventh Framework Programme (FP7/2007-2013) under Grant agreement number PITN-GA-2008-214505 and the Deutsche Forschungsgemeinschaft (DFG).
H.S. received a scholarship from the German Academic Exchange Service/Deutscher Akademischer Austausch Dienst (DAAD).

\section{References}

Adamek, M., H. Syakuri, S. Harris, KŁ. Rakus, G. Brogden, M. Matras, I. Irnazarow, and D. Steinhagen. 2013. Cyprinid herpesvirus 3 infection disrupts the skin barrier of common carp (Cyprinus carpio L.). Veterinary Microbiology, 162: 456-470

Alexandre, M.D., B.G. Jeansonne, R.H. Renegar, R. Tatum, and Y.H. Chen. 2007. The first extracellular domain of claudin-7 affects paracellular $\mathrm{Cl}$ permeability. Biochemical and Biophysical Research Communications, 357 (1): 87-91.

Altschul, S.F., W. Gish, W. Miller, E.W. Myers, and D.J. Lipman. 1990. Basic local alignment search tool. J. Mol. Biol., 215 (3): 403-10.

Angelow, S., R. Ahlstrom, and A.S. Yu. 2008. Biology of claudins. Am J. Physiol. Renal. Physiol., 295 (4): F867-76.

Anisimova, M. and O. Gascuel. 2006. Approximate likelihood-ratio test for branches: A fast, accurate, and powerful alternative. Syst. Biol., 55 (4): 539-52.

Bagherie-Lachidan, M., S.I. Wright, and S.P. Kelly. 2008. Claudin-3 tight junction proteins in Tetraodon nigroviridis: cloning, tissuespecific expression, and a role in hydromineral balance. American Journal of Physiology - Regulatory, Integrative and Comparative Physiology, 294 (5): R1638R1647.

Berkes, J., V.K. Viswanathan, S.D. Savkovic, and G. Hecht. 2003. Intestinal epithelial responses to enteric pathogens: effects on the tight junction barrier, ion transport, and inflammation. Gut, 52 (3): 439-451.

Chasiotis, H. and S.P. Kelly. 2011. Effect of cortisol on permeability and tight junction protein transcript abundance in primary cultured gill epithelia from stenohaline goldfish and euryhaline trout. General and Comparative Endocrinology, 172 (3): 494-504.

Colegio, O.R., C. Van Itallie, C. Rahner, and J.M. Anderson. 2003. Claudin extracellular domains determine paracellular charge selectivity and resistance but not tight junction fibril architecture. Am J. Physiol. Cell. Physiol., 284 (6): C1346-54.

Dereeper, A., V. Guignon, G. Blanc, S. Audic, S. Buffet, F. Chevenet, J.F. Dufayard, S. Guindon, V. Lefort, M. Lescot, J.M. Claverie, and O. Gascuel. 2008. Phylogeny.fr: robust phylogenetic analysis 
for the non-specialist. Nucleic Acids Res., 36 (Web Server issue): W465-9.

Dereeper, A., S. Audic, J.M. Claverie, and G. Blanc. 2010. BLAST-EXPLORER helps you building datasets for phylogenetic analysis. BMC Evol. Biol., 10: 8.

Edgar, R.C. 2004. MUSCLE: multiple sequence alignment with high accuracy and high throughput. Nucleic Acids Res., 32 (5): 1792-7.

Gasteiger, E., A. Gattiker, C. Hoogland, I. Ivanyi, R.D. Appel, and A. Bairoch. 2003. ExPASy: the proteomics server for in-depth protein knowledge and analysis. Nucleic Acids Res., 31 (13): 3784-3788.

Groschwitz, K.R. and S.P. Hogan. 2009. Intestinal barrier function: Molecular regulation and disease pathogenesis. Journal of Allergy and Clinical Immunology, 124 (1): 3-20.

Guindon, S. and O. Gascuel. 2003. A simple, fast, and accurate algorithm to estimate large phylogenies by maximum likelihood. Syst. Biol., 52 (5): 696-704.

Guttman, J.A. and B.B. Finlay. 2009. Tight junctions as targets of infectious agents. Biochimica et Biophysica Acta (BBA) Biomembranes, 1788 (4): 832-841.

Hirokawa, T., S. Boon-Chieng, and S. Mitaku. 1998. SOSUI: classification and secondary structure prediction system for membrane proteins. Bioinformatics, 14 (4): 378-379.

Kollmar, R., S.K. Nakamura, J.A. Kappler, and A.J. Hudspeth. 2001. Expression and phylogeny of claudins in vertebrate primordia. Proceedings of the National Academy of Sciences of the United States of America, 98 (18): 10196-10201

Lal-Nag, M. and P. Morin. 2009. The claudins. Genome Biology, 10 (8): 235.

Larkin, M.A., G. Blackshields, N.P. Brown, R. Chenna, P.A. McGettigan, H. McWilliam, F. Valentin, I.M. Wallace, A. Wilm, R. Lopez, J.D. Thompson, T.J. Gibson, and D.G. Higgins. 2007. Clustal W and Clustal X version 2.0. Bioinformatics, 23 (21): 29472948.

Loh, Y.H., A. Christoffels, S. Brenner, W. Hunziker, and B. Venkatesh. 2004 Extensive expansion of the claudin gene family in the teleost fish, Fugu rubripes. Genome Research, 14 (7): 1248-1257.

Mitaku, S. and T. Hirokawa. 1999. Physicochemical factors for discriminating between soluble and membrane proteins: hydrophobicity of helical segments and protein length. Protein Engineering, 12 (11) : 953-957.

Mitaku, S., T. Hirokawa, and T. Tsuji. 2002. Amphiphilicity index of polar amino acids as an aid in the characterization of amino acid preference at membraneâ€"water interfaces. Bioinformatics, 18 (4): 608-616.
Morita, K., M. Furuse, K. Fujimoto, and S. Tsukita. 1999. Claudin multigene family encoding four-transmembrane domain protein components of tight junction strands. Proceedings of the National Academy of Sciences of the United States of America, 96 (2): 511-516.

Pagni, M., V. Ioannidis, L. Cerutti, M. Zahn-Zabal, C. V. Jongeneel, and L. Falquet. 2004. MyHits: a new interactive resource for protein annotation and domain identification. Nucleic Acids Res., 32 (Web Server issue): W332-5.

Pagni, M., V. Ioannidis, L. Cerutti, M. Zahn-Zabal, C.V. Jongeneel, J. Hau, O. Martin, D. Kuznetsov, and L. Falquet. 2007. MyHits: improvements to an interactive resource for analyzing protein sequences. Nucleic Acids Res., 35 (Web Server issue): W433-7.

Prasad, S., R. Mingrino, K. Kaukinen, K.L. Hayes, R.M. Powell, T.T. MacDonald, and J.E. Collins. 2005. Inflammatory processes have differential effects on claudins 2, 3 and 4 in colonic epithelial cells. Lab. Invest., 85 (9): 1139-1162.

Rozen, S. and H. Skaletsky. 1999. Primer3 on the WWW for general users and for biologist programmers. Bioinformatics Methods and Protocols, 132: 365-386.

Sandbichler, A.M., M. Egg, T. Schwerte, and B. Pelster. 2011. Claudin 28b and F-actin are involved in rainbow trout gill pavement cell tight junction remodeling under osmotic stress. J. Exp. Biol., 214 (Pt 9): 1473-87.

Schulzke, J.D., S. Ploeger, M. Amasheh, A. Fromm, S. Zeissig, H. Troeger, J. Richter, C. Bojarski, M. Schumann, and M. Fromm. 2009. Epithelial tight junctions in intestinal inflammation. Ann. N.Y. Acad. Sci., 1165: 294-300.

Syakuri, H., M. Adamek, G. Brogden, K.Å. Rakus, M. Matras, I. Irnazarow, and D. Steinhagen. 2013. Intestinal barrier of carp (Cyprinus carpio L.) during a cyprinid herpesvirus 3-infection: Molecular identification and regulation of the mRNA expression of claudin encoding genes. Fish \& Shellfish Immunology, 34 (1): 305-314.

Syakuri, H., V. Jung-Schroers, M. Adamek, G. Brogden, I. Irnazarow, and D. Steinhagen. 2014. Beta-glucan feeding differentiated the regulation of mRNA expression of claudin genes and prevented an intestinal inflammatory response post Aeromonas hydrophila intubation in common carp, Cyprinus carpio L. Journal of Fish Diseases, 37: 149-156 
Tipsmark, C.K., P. Kiilerich, T.O. Nilsen, L.O.E. Ebbesson, S.O. Stefansson, and S.S. Madsen. 2008 ${ }^{\mathrm{a}}$. Branchial expression patterns of claudin isoforms in Atlantic salmon during seawater acclimation and smoltification. American Journal of Physiology - Regulatory, Integrative and Comparative Physiology, 294 (5): R1563R1574.

Tipsmark, C.K., J.A. Luckenbach, S.S. Madsen, P. Kiilerich, and R.J. Borski. 2008 . Osmoregulation and expression of ion transport proteins and putative claudins in the gill of southern Flounder (Paralichthys lethostigma). Comparative Biochemistry and
Physiology - Part A: Molecular \& Integrative Physiology, 150 (3): 265-273.

Turner, J.R. 2009. Intestinal mucosal barrier function in health and disease. Nat. Rev. Immunol., 9 (11): 799-809.

Van Itallie, C.M. and J.M. Anderson. 2004. The molecular physiology of tight junction pores. Physiology (Bethesda), 19: 331-8.

Van Itallie, C.M. and J.M. Anderson. 2006. Claudins and epithelial paracellular transport. Annu. Rev. Physiol., 68: 403-29.

Wen, H., D.D. Watry, M.C. Marcondes, and H.S. Fox. 2004. Selective decrease in paracellular conductance of tight junctions: role of the first extracellular domain of claudin-5. Mol. Cell. Biol., 24 (19): 8408-17. 